\title{
THE MEDICAL TREATMENT OF CONGENITAL PYLORIC STENOSIS*
}

BY

\author{
ELISABETH SVENSGAARD, M.D. \\ (From the Children's Department of the University Clinic, the Rigshospital, \\ Copenhagen, Denmark: Director, Prof. C. E. Bloch.)
}

Even outside paediatric circles the clinical picture of congenital stenosis of the pylorus is nowadays well known, although Bloch as late as 1906 wrote that 'stenosis pylori congenita' was not recognized by paediatricians until several years after Hirschsprung described it in 1887, and even then in 1906 it was little known to the medical profession in general. Since then the disease has been much described and discussed. That it is not an unusual malady appears from the fact that in the Children's Department of the Rigshospital alone more than 200 cases of it have been treated in the course of twenty-three years.

The various authorities agree with regard to the clinical description, but there the unanimity ends. There are highly diverse opinions as to the pathogenesis, and equal disagreement as to the treatment. As regards the pathogenesis only some of the usual points of view which have come to the fore will be touched on here, without any definite conclusions.

\section{Pathogenesis.}

Wernstedt, who has devoted much time to investigating the pathogenesis of the disease, believes that its spastic nature is indisputable but he doubts whether there can be spasm without hypertrophy of the pylorus, and therefore whether hypertrophy of the pylorus is congenital or a secondary compensatory hypertrophy. Monrad believes it to be a question of congenital hypertrophy of the pylorus with intermittent spasms and that both tend to disappear as the infant grows older. Bloch considers the cause of the disease to be a remnant from foetal life, of the foetal pyloric canal, with hypertrophy and spasm of its musculature and compensatory hypertrophy of the rest of the musculature of the stomach. When this foetal formation disappears and the pylorus is closed by a sphincter the symptoms vanish. There is nothing to indicate that the patients have any trace of the disease in later life. Povl Hertz believes that the malady is due to a spasm which is a secondary factor in a congenital, hypertrophied pylorus musculature. Heile and others think that it is possible to find pyloric spasm both with and without hypertrophy of the pylorus. Meuwissen and Sloof, on the basis of x-ray examinations, believe that one may conclude that the hypertrophy of the muscle is probably a result of the spasm. Lehmann believes it to be a question of a congenital, functional

* Translated from the Danish by Elsie-Marie Werner Kornerup, B.A, 
pyloric obstruction with compensatory muscle hypertrophy and hyperirritability of the vagus centre. Various other authors, especially French and American, believe that there are two diseases, pyloric spasm and pyloric stenosis, which certainly cannot be differentiated from one another except by demonstration of the thickened pylorus. Peiffer believes that the malady arises from vagotonus or sympathetic hypotonus with relative vagotonus.

In all cases, spontaneous recovery takes place provided the patient does not die of inanition during the course of the disease. Treatment must therefore aim at preventing this.

\section{Principles of treatment.}

There has been a great deal of discussion about the principles involved in treatment. Two main points of view are outstanding: i.e., preference for surgical measures on the one hand and, on the other, conservative medical treatment. In some places both methods are in use, depending upon the nature of the case. There seems, however, to be an increasing tendency towards preference for surgical measures.

The medical treatment at the different clinics varies to some extent. There is, however, conformity of opinion as to the fact that first of all the dehydration must be combatted with saline, given subcutaneously, intravenously and per rectum. The methods of nourishment, on the other hand, vary greatly. In some hospitals frequent feeds, every hour or every two hours, are given. In this case the quantity given is small, beginning with 10 or $20 \mathrm{gm}$. at a time. Sometimes common milk-modifications are chosen sometimes human milk or butter-milk. Concentrated porridge-like mixtures, consisting of, for example, rusks softened in evaporated milk, have been warmly recommended.

Kleinschmidt (now of Cologne) gave at the University Clinic in Hamburg human milk evaporated in vacuo until it was of the consistency of porridge (reported by Ebert). Casein milk, baby foods, such as, for example, larosan, have also been recommended. As for medicines, atropin has been used sometimes and during recent years, use of eumydrin has been occasionally reported. None of the remedies seems to have been given consistently, and widely differing judgment has been passed upon their effect. Papaverin and vasano have also been tried. Eckstein believes that the vomiting is due to hyper-irritation of the vagus centre and he therefore recommends hypnotics, such as adalin, noctal and somnifen. He has seen good results in eight cases thus treated. Washing out the stomach in order to remove its decomposing contents and thereby avoiding the complication of gastritis is still often undertaken. Nourishment has also been given through a duodenal tube.

Surgical therapy is by far more uniform. Gastro-enterostomy was long ago discarded in favour of Rammstedt's operation which consists of cutting through the pyloric musculature longitudinally, so that the mucous membrane is reached through the muscle bundles and the pylorus made to gape. This operation, with slight modification has become almost universal.

The indications for operation are variously regarded. Rammstedt and others advise operation when, after eight or ten days of medical treatment, there is no improvement in the patient's condition. All agree that the 
success of the operation depends upon the child's not being too ill at the time. Bayer goes so far as to say that the condition of the child before the operation is more important for the success of the latter than the surgical technique. All authorities lay great stress upon the post-operative treatment, and the necessity of co-operating with the paediatric department is emphasized. Those who favour operation state that as a consequence the symptoms disappear quickly, in fact, often suddenly, and the duration of the disease is shortened, since the after-treatment often need only extend over a period of from two to four weeks.

\section{Previous results.}

The following statistics show the results of medical and surgical treatment respectively in various clinics.

TABLE 1.

Medical treatment.

\begin{tabular}{|c|c|c|c|c|c|c|c|}
\hline Yiar. & \multicolumn{5}{|c|}{ Paediatrician. } & No. of Cases. & Mortality. \\
\hline 1921 & Frivere: & ANI & HAMIITON & $\ldots$ & $\ldots$ & 57 & $\begin{array}{c}\text { PER (CENT. } \\
3 \cdot \overline{5}\end{array}$ \\
\hline 19222 & IBRAHIM & & $\ldots$ & $\ldots$ & $\ldots$ & .2 & $1 \cdot 9$ \\
\hline 1928 & Monrad & & $\ldots$ & $\ldots$ & $\ldots$ & $2 \cdot 28$ & $4 \cdot 4$ \\
\hline 1930 & WOLFF & $\ldots$ & $\ldots$ & $\ldots$ & $\ldots$ & 98 & $2 \cdot 2$ \\
\hline 1933 & FAXÉN & $\ldots$ & $\ldots$ & $\ldots$ & ... & 126 & $3 \cdot 3$ \\
\hline
\end{tabular}

TABLE 2.

Surgical treatment.

\begin{tabular}{|c|c|c|c|c|c|c|}
\hline YEAR. & \multicolumn{4}{|c|}{ Pandiatrician. } & No. OF cases. & Mortality. \\
\hline 1926 & ABt AND STRAT & & $\ldots$ & $\ldots$ & 221 & $\begin{array}{c}\text { PER CENT. } \\
3\end{array}$ \\
\hline 1926 & Heile $\ldots$ & $\ldots$ & $\ldots$ & ... & 42 & $2 \cdot 4$ \\
\hline 1927 & Tisdalu, Poole & $A \times D F$ & $0 W x$ & $\ldots$ & 120 & $13 \cdot 2$ \\
\hline 1929 & HABERER & $\ldots$ & $\ldots$ & $\ldots$ & $3 \pi$ & $2 \cdot 2$ \\
\hline 1932 & Haberer & $\ldots$ & $\ldots$ & $\ldots$ & 73 & $5 \cdot 5$ \\
\hline 1934 & Haberer & ... & ... & $\ldots$ & 102 & $6 \cdot 9$ \\
\hline 1930 & R.AMMSTEDT & ... & $\ldots$ & $\ldots$ & 60 & $3 \cdot 3$ \\
\hline 1933 & Nisser anil Bo & CKER & $\ldots$ & $\ldots$ & 50 & 8 \\
\hline
\end{tabular}


TABLE 3.

Treatmint partly medical, partly surgical.

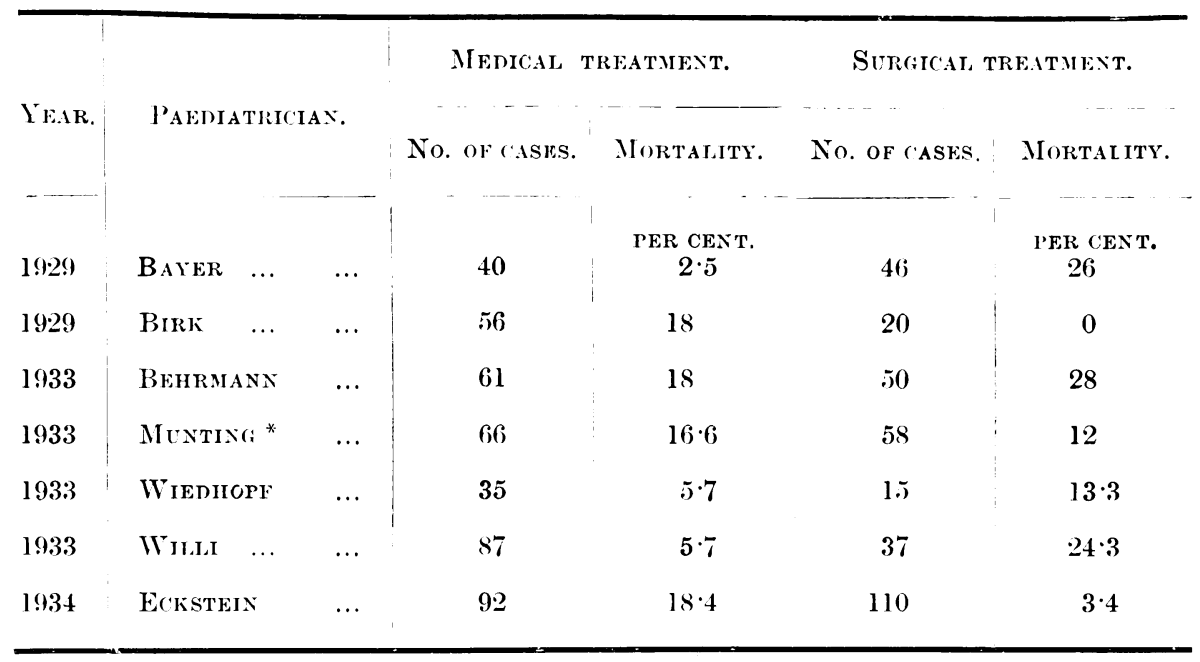

* In Munting's material, the first 20 who received operative treatment are the same as in Birk's statistics. All cases of death, therefore, occurred in the last 38 cases.

In 1930 Rammstedt had collected information about 1,842 cases from sixty different clinics. Of these, 1,345 had received medical treatment with a mortality of 16 per cent. and 497 were treated surgically with a mortality of 22.5 per cent. The statistics of the mortality for those treated medically as well as surgically are, on the average, more encouraging in those hospitals which confine themselves to one of the two methods. This may indicate that hospital discipline and consistent treatment are of importance. On the whole, the mortality rate seems to be lower in the case of medical treatment.

\section{Present material.}

In spite of the best possible technique it is scarcely possible to avoid a certain mortality as a direct result of the operation. In order to counterbalance the growing enthusiasm for operation, it is felt to be justified to publish the following material from the Children's Department of the Rigshospital, where the treatment has always been exclusively medical. $\dagger$ The material covers the period from 1911 to 1934. During this time 224 patients were treated. A number of slight cases which recovered rapidly following admission to the hospital and received no special treatment have, however, been deducted, and also a few in which the diagnosis was made only on the basis of gastric peristalsis and vomiting, and four cases in which death occurred, the details of which are as follows:-

$\dagger$ The numerical statistical work was undertaken in collaboration with (x. Rasch, Ph.D, 
One patient died immediately after admission; another within twentyfour hours of pyelonephritis; a third on the second day with hyperpyrexia and convulsions due to nephritis; and finally, a patient, aged one week, who had been born six weeks prematurely. In this case no diagnosis was made, but autopsy revealed pyloric stenosis. The patient's vomit had been bile-stained.)

The final material, therefore, consists of $\mathbf{1 7 9}$ cases. In order to establish the diagnosis of congenital pyloric stenosis the following signs and symptoms were required:- the presence of projectile vomiting, gastric peristalsis, emaciation and constipation. Furtherfore, in most cases (155, i.e. 87 per cent.) there was a palpable pyloric tumour. In a few cases constipation was not especially pronounced but the other symptoms were typical. In sixtytwo cases there were traces of blood in the vomit and melaena. X-ray examinations were not made.

As in other collected series of these cases it was found that by far the majority of patients were boys (135 boys and 44 girls, i.e. 75 per cent. boys). Sex seems, however, to play no part, as far as the course of the disease is concerned. The present results agree with those of Faxén that there is no evidence of any seasonal distribution. Hereditary tendency was observed in five cases. In one, the father had had pyloric stenosis. In the case of three patients who were the second children in a family, the eldest children (two boys and one girl) had also had the disease. In the case of one child, the fourth in the family, two brothers had had pyloric stenosis. In one case the mother was said to be 'nervous,' in another, an habitual drunkard. No mention was found in the other case-histories of nervous disorders in the parents.

Ninety-nine, i.e. 56 per cent. of the children, had been breast fed until the appearance of symptoms. Only thirty-five, i.e. 20 per cent., had received entirely artificial feeding. This proportion has been the same throughout the years. The number of breast-fed infants is scarcely larger than for any other group of infants. There are, however, no reliable figures as to the proportion of breast-fed and bottle-fed babies among the population during the corresponding period. The type of feeding previous to the disease does not seem to influence its course.

The following complications were found: Minor catarrhal conditions, nine cases; tonsillitis, four; thrush, one; bronchitis, one; bronchopneumonia, three; otitis media, seven; pyuria, twelve; albuminuria, three; septicaemia, one; pemphigus, one; pertussis, two; varicella, two; dyspepsia, four; inguinal hernia, thirteen; prolapse of rectum, one; pes equino-varus, one; icterus neonatorum, two; prematurity, three; simple anaemia, ten.

The material falls naturally into three groups, in which three different therapeutic measures have been systematically used.

Group I. 1911-1927. Gastric lavage and, to some extent, feeding through a duodenal tube.

Group II. 1922-1927. Atropin.

Group III. 1927-1934. Eumydrin.

(Some of the patients in groups I and II have been discussed by Hertz in 1915 and Johannesen in 1924.)

In 147 cases the diagnosis under which the patients had been sent to the hospital was congenital pyloric stenosis or suspicion of it. Other diagnoses have been: infantile atrophy, dyspepsia, enteritis, gastroenteritis, melaena, vomiting, observation for ileus and oesophageal stricture. 
It appears that in recent years the physicians consulted send the patients to the hospital at an earlier stage. Thus it is seen that within four weeks after the onset of the disease 55 per cent. of the patients were admitted in the first group, 64 per cent. in the second group and 72 per cent. in the third group. The duration of home treatment has apparently become shorter. It is rarer now for a patient to be admitted in a state of extreme atrophy, but none the less, 59 per cent. of the patients in group III weighed less than at birth.

With regard to further therapeutic details, it must be emphasized that common to all three groups is the thorough treatment of dehydrated patients with saline. Until the diuresis is satisfactory, saline is given in the form of subcutaneous injections, consisting of 100 c.c. at a time, once or twice a day. At the same time, and later alone, saline is given per rectum (75 to 100 c.c. for a couple of weeks). After a time this usually causes some rectal irritation which makes the patient evacuate the saline at once. The theoretical basis for this saline therapy has been expounded in recent years by Schnorr, Seckel and others. It has been shown that because of the severe vomiting the body becomes extremely deficient in chloride and the patient can go into a hypochloraemic coma. In view of this Seckel disapproves of gastric lavage which makes the body still more deficient in chloride.

The principles regarding nourishment have been more or less the same throughout the years. Feeds are not given any more frequently than is usual at that age, i.e. seven a day, but only small quantities are given, i.e. 60 to 75 c.c. at a time. Milk, diluted with barley-water, is given but the milk mixture is more concentrated than for healthy infants of the same age. In recent years 6 per cent. sugar has been added instead of the customary 2 per cent. Buttermilk was widely used the first few years, but since it did not appear to offer any particular advantages, it is now an exception to give it. When the patient has drunk half the contents of a bottle, a pause in the feed is made and the bottle removed for five or ten minutes. If vomiting takes place 35 c.c. more are given. Human milk is used extensively, a few of the feeds consisting of it, the rest of milk modifications. In order not to waste the human milk it is not given as long as the vomiting is severe. Nutritional enemas, as recommended for example by Ibrahim, have not been given. In view of the danger of contagion, these patients are usually kept in small wards, or, if several are admitted at one time, in one langer ward. Care is taken not to have them in the same room with patients suffering from catarrhal or other contagious diseases. Furthermore, there are no patients over one year of age on the floor of this ward.

As already mentioned, during the period from 1922 to 1927 the outstanding feature of the therapy was gastric lavage to remove the decomposing contents of the stomach and, from 1916, feeding through a duodenal tube. Five out of seventy-one patients died. In four of the cases death must be attributed entirely to emaciation resulting from the 
pyloric stenosis. In the fifth case there was broncho-pneumonia simultaneously.

During the second period, at Arne Johannesen's incentive, a 1 in 1,000 solution of atropine sulphate was given by mouth, beginning with one drop (=0.05 mgm.) per dose, and increasing to, at the most, two drops, seven times a day, when seen to be well tolerated. Sometimes this treatment was kept up for two or three months until the vomiting had ceased and the patient was thriving satisfactorily. Now and then atropine poisoning was observed. In this event, no atropine was given at the next feed or possibly the dose was decreased, or the treatment stopped for a few days and then cautiously begun again. In some cases the temperature was raised to about $38^{\circ}$ C. $\left(100 \cdot 4{ }^{\circ}\right.$ F.), a fact which must be attributed to the atropine. No serious cases of atropine poisoning were observed. A few patients did not respond to the treatment. In the beginning of this period a few of the patients were still treated with gastric lavage, a method of treatment which has gradually been abandoned. The patients who received atropine stopped vomiting more quickly and thrived better than previously. Three out of forty-seven died. In all three cases the cause of death was emaciation resulting from pyloric stenosis. One case was complicated by broncho-pneumonia.

In 1927 treatment was started with eumydrin which Paul Drucker, at that time on the staff of the department, had found to be a comparatively non-poisonous, yet particularly efficacious atropine compound. Eumydrin is atropinemethylnitrate. It is said to be fifty times less poisonous than atropine, although the efficacious dose is only two or three times larger. Usener and a few others (Ebert, Herbst and Lindquist) recommended it as being worth a trial in congenital pyloric stenosis. In this department it is given in a 1 in 10,000 solution. Since such a solution does not keep, a fresh one is always given, i.e. not more than one week old. Five c.c. of this, corresponding to $0.5 \mathrm{mgm}$. per dose, are given seven times a day, half an hour before each feeding. During recent years, however, a start has been made with only $0.25 \mathrm{mgm}$. per dose, which in a number of cases has proved to be sufficient.

This treatment is kept up for weeks, i.e., until the patient has not vomited for a week or more. In some cases the vomiting begins again after the eumydrin has been discontinued. Providing this occurs eumydrin is again given until there has been no vomiting for a week or longer. It is extremely unusual to have to repeat the treatment a third time. Serious recurrences have not been observed. The skin of the patients is often seen to be a clear, flaming red and a few times there has been a rise of temperature up to about $38^{\circ}$ C. $\left(100 \cdot 4^{\circ}\right.$ F.). Apparently this must be attributed to the eumydrin. In these cases no eumydrin is given at the next feeding. The attack always passes very quickly. Friedlaender has described a case of eumydrin poisoning with hyperpyrexia and death (no autopsy). Monrad reported that a brother of the patient also reacted with hyperpyrexia when given eumydrin. It may, therefore, be concluded that this was a case of idiosyncrasy. 
As mentioned above, neither during eumydrin nor atropine treatment, has severe poisoning been encountered. The precautionary measure is always observed not to give these drugs as long as the patient is in an extremely dehydrated condition: not until the introduction of saline has produced satisfactory diuresis is the medicine given.

During the period of eumydrin treatment, two out of sixty-one patients died. In one case all the symptoms of pyloric stenosis had disappeared several weeks before death took place, and the patient was thriving well. He contracted a severe pyelonephritis, and death must be attributed to that alone. Autopsy revealed a medium-sized pyloric tumour and a severe bilateral pyelonephritis.

In the other case the patient did not respond to eumydrin treatment.

When admitted to the department she was seven weeks old and weighed $200 \mathrm{gm}$. less than at birth. She had pes equino-varus of both feet. The vomit contained blood and she continued bleeding for a long time following the needle-prick for the saline injection. As stated above, the eumydrin had no effect upon her and it was therefore discontinued at the end of three weeks. The patient's temperature, upon admission was $38.4^{\circ} \mathrm{C}$. $\left(101 \cdot 2^{\circ} \mathrm{F}\right.$.) and next day (before she had received eumydrin) it was $39^{\circ} \mathrm{C}$. $\left(102 \cdot 2^{\circ} \mathrm{F}.\right)$. It was normal during the next ten days but rose again to $38^{\circ}$ C. $\left(100 \cdot 4^{\circ}\right.$ F.) and $39^{\circ}$ C. $\left(102 \cdot 2^{\circ}\right.$ F.). On the last day (after the eumydrin had been abandoned) her temperature rose to $41 \cdot 2^{\circ} \mathrm{C} .\left(106 \cdot 6^{\circ} \mathrm{F}\right.$.). There is no definite explanation for this rise of temperature. There was no pyuria, but slight albuminuria. At autopsy a pyloric tumour was found as well as dilatation of the stomach and oesophagus and a fatty liver.

In this case, medical treatment did not help, but in view of the patient's debility and haemorrhagic diathesis, neither could surgical treatment have saved her.

\section{Discussion of results.}

It is common to evaluate the efficacy of a method of treating congenital pyloric stenosis in the light of its mortality rate. This way of regarding it, however, gives only a highly imperfect picture of what is achieved. As a rule, the material includes only a small number of patients and therefore one death can have considerable influence upon the figures: (cf. inter alia, Munting-Birk's statistics on patients treated surgically and Haberer's increasing mortality rate).

In our material in Group I, 5 out of 71 died, i.e. $7 \cdot 1$ per cent.

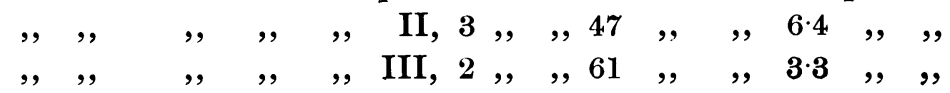

If the case is omitted in which death must be attributed to pyelonephritis a mortality rate of only 1.6 per cent. is obtained. The mortality rate is lowest in the case of patients treated with eumydrin, but in all three groups the figures are the same category. Only when the results of the treatment in the case of discharged patients are regarded is a clear impression obtained: it is found that eumydrin treatment is unquestionably the most successful. 
It is worth noting that all of the patients who died had blood in the vomit and melaena. Also, patients who recovered respond more slowly to the treatment when they have a tendency to bleed: 62 out of 179 had this tendency. In the first period there were 31 out of 71 , in the second, 15 out of 47 and in the third 16 out of 61 .

The following table will give a summary of the condition of the bleeders upon admission.

TABLE 4.

\begin{tabular}{|c|c|c|c|c|c|}
\hline Condition & GRoy' I & GROCI II & GROCP III & Totals & Parcentafile \\
\hline $\begin{array}{lll}\text { Atrophied } & \ldots & \ldots\end{array}$ & 10 & 6 & 5 & 21 & 34 \\
\hline Thin AND DEHYDRATED & 7 & 5 & 4 & 16 & 26 \\
\hline Thin $\ldots$ & 9 & 2 & 6 & 17 & 27 \\
\hline Not Enaciated & 5 & 2 & 1 & 8 & 13 \\
\hline Total & 31 & 15 & 16 & 62 & \\
\hline
\end{tabular}

The average length of time spent in the hospital (not including those that died) is respectively 120,102 and 102 days.

Patients without a tendency to bleed fall into the following groups as far as condition when admitted is concerned.

TABLE 5.

\begin{tabular}{|c|c|c|c|c|c|c|}
\hline Condition & & Group I & Grol' II & Grotr III & Totals & Plekcentacil \\
\hline AtrophIED $\quad \ldots$ & $\ldots$ & 16 & 6 & 6 & 28 & 24 \\
\hline THIN, DEHYDRATED & $\cdots$ & 10 & 10 & 22 & 42 & 36 \\
\hline $\begin{array}{lll}\text { This } & \ldots & . .\end{array}$ & $\ldots$ & $1 \mathrm{i}$ & 12 & s & 31 & 26 \\
\hline Not enaciated & $\ldots$ & 3 & 4 & 9 & 16 & 14 \\
\hline \multicolumn{2}{|c|}{ TotaI } & 40 & 32 & 4.) & 117 & \\
\hline
\end{tabular}

The number of days these patients (non-bleeders) spent in the hospital is on the average, respectively 101, 94 and 69 .

The figures show that the patients with a tendency to bleed were more seriously ill than the others, even though when admitted they were not always the most emaciated or apparently the most miserable, and although the loss of blood in itself was not considerable. It might be thought that the bleeding was due to a mechanical lesion of the mucous membrane of the stomach, brought about by the severe vomiting, but this does not account for the more severe course of the disease in the case of 
these patients. Presumably, the bleeding is rather an indication of haemorrhagic diathesis which is not congenital in these children, but appears at the same time as the first violent symptoms of the disease, and is a result of the severe vomiting with its great loss of fluid and salts. The body suffers from acute inanition, which also makes its presence known through the glycosuria often found in these children at the beginning, and which must be classified as hunger-glycosuria. Frequently the inanition has not yet reached the point at which it is recognizable through considerable loss of weight. The tendency to bleeding disappears when the feeding is in order. This applies to both breast-fed and bottle-fed infants. The seriousness of the bleeding symptom does not seem to have been previously emphasized as strongly as it obviously deserves to be.

The influence which the duration of the illness prior to admission has upon the condition upon admission, is shown by the following table.

TABLE 6.

\begin{tabular}{|c|c|c|c|c|c|c|}
\hline \multirow{2}{*}{$\begin{array}{l}\text { Condition Whes } \\
\text { ADMITTED }\end{array}$} & \multicolumn{2}{|c|}{ BLEeders } & \multicolumn{2}{|c|}{ NON-BIEEDERS } & \multicolumn{2}{|c|}{ Total } \\
\hline & $\begin{array}{l}\text { No. OF } \\
\text { PATIEYTS }\end{array}$ & $\begin{array}{l}\text { LENGTH OF } \\
\text { ILLNESS IN } \\
\text { WEEKS }\end{array}$ & $\begin{array}{l}\text { No. of } \\
\text { PATIENTS }\end{array}$ & $\begin{array}{l}\text { LENGTH OF } \\
\text { ILLNESS IN } \\
\text { WEEKS }\end{array}$ & $\begin{array}{c}\text { No. of } \\
\text { PATIENTS }\end{array}$ & $\begin{array}{c}\text { LENGTH OF } \\
\text { ILLNESS IN } \\
\text { WEEKS }\end{array}$ \\
\hline АткорнікD & 21 & 56 & 28 & $4 \cdot \tilde{5}$ & 49 & 5) \\
\hline TIIN, DEHYDRATED ... & 17 & $3 \cdot 6$ & 42 & $3 \cdot 9$ & 59 & $3 \cdot 8$ \\
\hline Thin ... & 16 & $3 \cdot \overline{5}$ & 32 & $4 \cdot 1$ & 48 & $3 \cdot 9$ \\
\hline Not emaciated & 8 & $2 \cdot 6$ & 15 & $2 \cdot 6$ & 23 & $2 \cdot 6$ \\
\hline Total & 62 & $4 \cdot 1$ & 117 & $4 \cdot 0$ & 179 & $4 \cdot 0$ \\
\hline
\end{tabular}

The condition upon admission is seen to be in a high degree dependent upon how much time elapsed previous to it. There is not any appreciable difference between bleeders and non-bleeders, in this respect.

If all of the patients are taken collectively it is seen that in all three periods, on the average, the weight at birth is good but that the patients are considerably emaciated upon admission.

TABLE 7 .

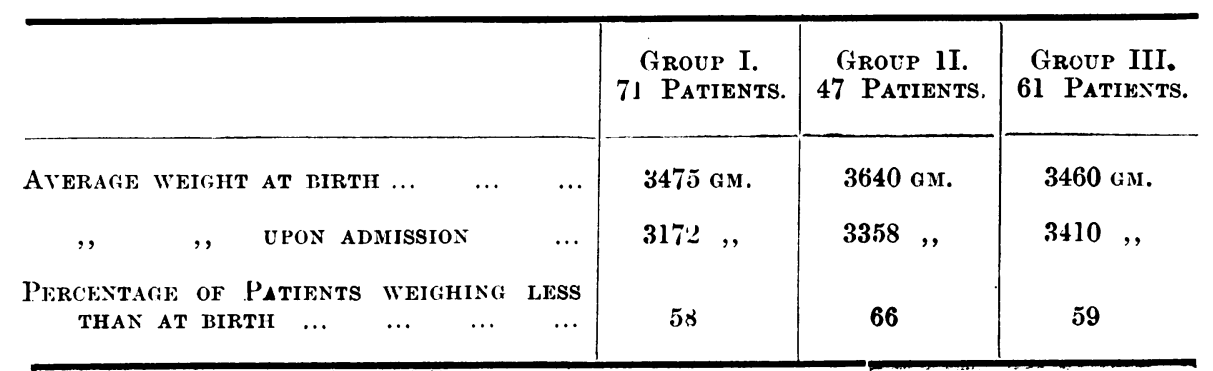


In by far the majority of cases the first symptoms appear between the second and fifth week of life.

TABLE 8.

\begin{tabular}{|c|c|c|c|c|c|c|c|}
\hline \multicolumn{5}{|c|}{ SYMPTONS BEGAN. } & \multirow{2}{*}{$\begin{array}{c}\text { Group I. } \\
13\end{array}$} & \multirow{2}{*}{$\frac{\text { GROUP II. }}{3}$} & \multirow{2}{*}{$\frac{\text { GRoup III. }}{2}$} \\
\hline A't BIRTH & $\ldots$ & $\ldots$ & $\ldots$ & $\ldots$ & & & \\
\hline lST WEEK & $\ldots$ & $\ldots$ & $\ldots$ & $\ldots$ & 8 & 2 & 5 \\
\hline $2 \times \mathrm{D}$, & $\ldots$ & $\ldots$ & $\ldots$ & $\ldots$ & 13 & 16 & 16 \\
\hline $3 \mathrm{RD}$, & $\ldots$ & $\ldots$ & $\ldots$ & $\ldots$ & 14 & 11 & 17 \\
\hline $4 \mathrm{Tн}$, & $\ldots$ & $\ldots$ & $\ldots$ & $\ldots$ & 2 & 4 & 6 \\
\hline $5 \mathrm{TH}$, & $\ldots$ & $\ldots$ & $\ldots$ & $\ldots$ & 14 & 8 & 9 \\
\hline $6 \mathrm{TH},$, & $\ldots$ & $\ldots$ & $\ldots$ & $\ldots$ & 4 & 0 & 3 \\
\hline Fти & $\ldots$ & $\ldots$ & $\ldots$ & $\ldots$ & 0 & 1 & 0 \\
\hline $8 \mathrm{TH}$, & $\ldots$ & $\ldots$ & $\ldots$ & $\ldots$ & 0 & 0 & 1 \\
\hline $9 \mathrm{TH} \& 10 \mathrm{TH}$ & EEK & $\ldots$ & $\ldots$ & $\ldots$ & 3 & 2 & 2 \\
\hline
\end{tabular}

TABLE 9.

Age upon admission.

\begin{tabular}{|c|c|c|c|c|c|c|c|}
\hline \multirow{2}{*}{\multicolumn{3}{|c|}{ LESS THAN 3 WEKKS }} & \multirow{2}{*}{$\ldots$} & & \multirow{2}{*}{$\mathrm{GrOUP}_{4} \mathrm{I}$} & \multirow{2}{*}{ GROUP II. } & \multirow{2}{*}{$\begin{array}{c}\text { GroUp III. } \\
--- \\
2\end{array}$} \\
\hline & & & & $\ldots$ & & & \\
\hline , & 3 & , & $\ldots$ & $\ldots$ & 7 & 7 & 10 \\
\hline , & $4 \cdot 5$ & , & $\ldots$ & $\ldots$ & 21 & 13 & 21 \\
\hline , & $6 \cdot 7$ & , & $\ldots$ & $\ldots$ & 15 & 13 & 9 \\
\hline :, & & ,, & $\ldots$ & $\ldots$ & 15 & 9 & 16 \\
\hline , & & NTHS & $\ldots$ & $\ldots$ & 7 & 4 & 1 \\
\hline ," & 4 & ," & $\ldots$ & $\ldots$ & 0 & 0 & 2 \\
\hline , & 5 & ," & $\ldots$ & $\ldots$ & 1 & 0 & 0 \\
\hline , & 6 & , & $\ldots$ & $\ldots$ & 1 & 0 & 0 \\
\hline
\end{tabular}

In order to examine more closely the effect of the treatment upon the patients, the following figures have been compiled from the material.

TABLE 10.

\begin{tabular}{|c|c|c|c|}
\hline $\begin{array}{l}\text { AVERAGE TIME WHEN VOMITING } \\
\text { STOPPEDAFTER PATIENTWASADMITTED }\end{array}$ & $\begin{array}{l}\text { GROUP I. } \\
6 \text { wEEKS. }\end{array}$ & $\begin{array}{l}\text { GROLP II. } \\
44 \text { WEEKS. }\end{array}$ & $\begin{array}{l}\text { GROUP III. } \\
3 \text { WEEKS }\end{array}$ \\
\hline $\begin{array}{cccc}\text { DURATION OF } & \text { THE } & \text { INITIAL LOSS } & \text { OF } \\
\text { WEIGHT } & \ldots & \ldots & \ldots\end{array}$ & $4 \frac{1}{2}$ WEEKS & $2 \frac{1}{2}$ WEEKS & 1 WEEK \\
\hline
\end{tabular}

* Short recurrences (one or two vomits) which occurred later in the course of the disease have not been taken into consideration. 
The conditions for bleeders and non-bleeders can be seen in more detail in the following table.

TABLE 11.

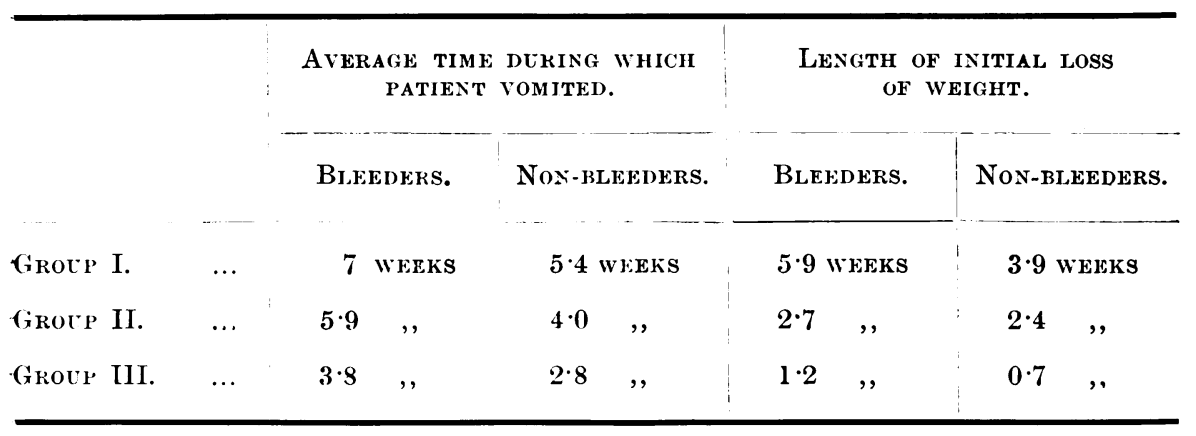

Marked progress is noticeable during the period of atropine treatment (group II). It is still more striking during that of the eumydrin treatment (group III), even as far as patients with a tendency to bleed are concerned. It is usually on the average only from one to two weeks, before the bleeders stop losing weight and less than a week for non-bleeders. In 56 per cent. of the cases the patients begin to gain weight a few days after the eumydrin treatment is begun.

Additional confirmation as to the excellence and superiority of eumydrin treatment compared to previous methods, is given by the following statistics :-

TABLE 12.

\begin{tabular}{|c|c|c|c|c|}
\hline & & GROUP I & Grove II & GROUP III \\
\hline & INITIAL LOSS OF WEIGHT & $0 \cdot 263$ KGM. & $0 \cdot 230$ k.x.M. & $0 \cdot 089$ KGM. \\
\hline 2. & No INItIaI, I.OSS of WeigutT & $\begin{array}{l}15 \text { CASES }=21 \\
\text { PER CENT. }\end{array}$ & $\begin{array}{l}6 \text { CASKS }=13 \\
\text { PER CENT. }\end{array}$ & $\begin{array}{l}31 \text { CASES }=50 \\
\text { PER CENT. }\end{array}$ \\
\hline 3. & $\begin{array}{l}\text { AVkRAGE WEIGHT WIIEN DIS- } \\
\text { CHARGED }\end{array}$ & $3 \cdot 995$ кам. & $4 \cdot 540$ к:м. & $4 \cdot 650$ кGм. \\
\hline 4. & $\begin{array}{l}\text { AVERAlis INCREASE IN WEIGHT } \\
\text { FROM WEIGHT WHEN AHMITTED }\end{array}$ & 0.950 кGM. & $1 \cdot 27 \mathrm{KGM}$ & $1 \cdot 27$ KGM. \\
\hline 5. & $\begin{array}{l}\text { AVERAGE INCREASE IN WEIGIIT } \\
\text { PER WELK }\end{array}$ & 62 (iм. & 91 Gi. & 122 GM. \\
\hline fi. & $\begin{array}{l}\text { AVERAGE INCREASE IN WEIGHT } \\
\text { PER WEEK FROM TIMK WHEN PA- } \\
\text { TILNT CEASHD TO LOSE WEIGHT }\end{array}$ & $117 \mathrm{GM}$. & 131 G.1. & $147 \mathrm{GM}$ \\
\hline 7. & $\begin{array}{l}\text { AVERAGE NO. OF INAYS SIENT IN } \\
\text { THE HOSPITAJ (FATAI. CASES } \\
\text { NOT INCLUDED) }\end{array}$ & 108 & 96 & 77 \\
\hline
\end{tabular}


Thus it is seen that the patients treated with eumydrin were in the hospital a much shorter time than those in the other two groups. This also applies to the patients who were atrophic and dehydrated upon admission and is illustrated by the following figures, which show that even these patients recovered much more rapidly.

TABLE 13.

\begin{tabular}{|c|c|c|c|c|c|c|}
\hline & \multicolumn{2}{|c|}{ GROOP I } & \multicolumn{2}{|c|}{ Groep II } & \multicolumn{2}{|c|}{ Grove III } \\
\hline & $\begin{array}{l}\text { A VERAGE } \\
\text { NO. OF DAYS } \\
\text { IN IIOSPITAL }\end{array}$ & $\begin{array}{c}\text { No. OF } \\
\text { PATIENTS }\end{array}$ & \begin{tabular}{|} 
AVERAGE \\
NO. OF DAYS \\
IN HOSPITAL
\end{tabular} & $\begin{array}{l}\text { No. of } \\
\text { PATiENTS }\end{array}$ & $\mid \begin{array}{c}\text { AVERAGE } \\
\text { NO.OF DAYS } \\
\text { IN HOSPITAL }\end{array}$ & $\begin{array}{l}\text { No. OF } \\
\text { PATIK. TS }\end{array}$ \\
\hline $\begin{array}{l}\text { ATROPHIE, DEHYHRATED } \\
\text { AND EMACIATED (NOT } \\
\text { COUNTING THE BIEEDERS) }\end{array}$ & 101 & 26 & 94 & 16 & 76 & 28 \\
\hline $\begin{array}{l}\text { 'THIS, BUT NOT DEHYDRA- } \\
\text { TED AND EMACIATEI) .. }\end{array}$ & 100 & 14 & 94 & 15 & 56 & 17 \\
\hline Totats & 101 & 40 & 94 & 31 & 69 & 45 \\
\hline
\end{tabular}

(This difference, as far as the bleeders are concerned, is not so striking, since, as already mentioned, koth in the case of atropine and eumydrin treatment the illness lasted 102 days, while in the first group it lasted 120 days.) If the figures dealing with the time spent in the hospital are examined, it is seen that it is of equal length in groups I and II, whether or not the patients were severely ill when admitted. It is only in group III that good condition upon admission served to shorten confinement to the hospital.

In the light of these results there can be no doubt as to the efficacy of eumydrin treatment. In order to secure such good results from medical treatment it is undeniably of the utmost importance that the nursing should be extremely careful and systematic. In this respect it must be recorded that the best possible support from the nurses, some of whom participated in the treatment from its very start, has been available. It devolves upon the nurses to see that feeding is correctly carried out, and that the eumydrin is given half an hour before feeding, in order that it may exercise its effect when the food enters the stomach. Furthermore, it depends, to some extent, upon the nurses whether or not a child escapes infection.

That the average duration of stay in hospital, in the case of patients receiving the eumydrin treatment, is comparatively long, (i.e. seventy-seven days), is due to the fact that it is not considered advisable to discharge patients before they have been gaining steadily in weight for a long time. They are therefore kept after the clinical symptoms have disappeared. One of the objections made to conservative treatment, especially by German paediatricians, is its long duration. This, however, can only be of 
consequence where public welfare is not able to assist the parents with the hospital expenses, or where there is a lack of accommodation in the hospital. The infant itself misses nothing by staying in the hospital.

It is evident, then, that the medical treatment in the Rigshospital Children's Department has been so satisfactory that there is no reason to change to surgical treatment, and still less, to accept the statement that not to operate is unjustifiable.

\section{Summary}

From 1911 to 1922 in the Children's Department of the Rigshospital, Copenhagen, congenital pyloric stenosis was treated by gastric lavage and feeding through a duodenal tube.

From 1922 to 1927 atropine was given and since 1927, eumydrin. During these periods respectively, 71, 47, and 61 patients were treated. The following summarizes the results in these three groups of patients: the average number of days spent in the hospital were 108, 96 and 77 and the mortality $7 \cdot 1$ per cent., $6 \cdot 4$ per cent. and $1 \cdot 6$ per cent. The average initial loss of weight (not including the fatal cases), was $0.263 \mathrm{kgm}$., $0.230 \mathrm{kgm}$., and 0.089 kgm. Average weight upon discharge was 3,995, 4,540 and 4,605 $\mathrm{kgm}$. The average increase in weight was $0.95,1.27$ and $1.27 \mathrm{kgm}$. The average increase in weight per week was 62, 91 and $122 \mathrm{gm}$.

The satisfactory results of eumydrin and its superiority to the two other methods of treatment are not emphasized so much in the light of its mortality rate, which is low in all three periods (and where the number of cases is also too small to permit the drawing of definite conclusions), but with regard to the results of the treatment as seen in the patients discharged.

Great stress is laid upon: (1) Saline administration while the patient is still in a dehydrated condition. (2) The giving of atropine and eumydrin only when the dehydration is over. (3) The giving of the drug half an hour before feeding.

The more serious prognosis for patients with a tendency to bleeding is emphasized.

\section{REFERENCES.}

Abt, I. A., \& Strauss, A., Am. J. Dis. Child., Chicago, 1926, XXXI, 894.

Bayer, W., Deutsche med. Wchnschr., Leipzig, 1929, LV, 2094.

Behrmann, W., Monatschr. f. Kinderh., Berlin, 1933, LV, 341.

Birk, W., Monatschr. f. Kinderh., Berlin, 1929, XLV, 481.

Bloch, C. E., Hospitalstid., Copenhagen, 1906, XIV, 125.

Ebert, M., Der Erfolg interner und chir. Therapie bei der Pylorusstenose, Hamburg, 1932.

Eckstein, A., Ztschr. f. Kinderh., Berlin, 1928, XLV, 423.

Eckstein, A., J. Am. Med. Ass., Chicago, 1929, XCIII, 1988.

Ernberg, H., \& Hamilton, B., Arch. Pediat., N.Y., 1921, XXXVIII, 771.

Faxén, N., Acta paediat., Uppsala, 1933, XIV, 388.

Friedlaender, A., Ugesk. f. laeger, Copenhagen, 1934, XCVI, 1376.

Haberer, H. v., Deutsche med. Wchnschr., Leipzig, 1929, LV, 2044; Deutsche Ztschr. f. Chir., Berlin, 1932, CCXXXV, 91; München. med. Wchnschr., Munich, 1934, i, 903. 
Heile, B., Klin. Wchnschr., Berlin, 1926, V, 192.

Herbst, C., Ztschr. f. Kinderh., Berlin, 1934, LVI, 122.

Hertz, P., Den medfodte Pylorusstenose, Copenhagen, 1915.

Ibrahim, J., Ergeb. d. inn. Med. u. Kinderh., Berlin, 1923, XXIV, 233.

Jchannesen, A., Ugeskr. f. Laeger, Copenhagen, 1924, LXXXIV, 113.

Lehmann, W., Ztschr. f. Kinderh., Berlin, 1931, L, $\overline{6} 91$.

Lindquist, N., Svenska läk.-tidning., Stockholm, 1931, XXVIII, 935.

Meuwissen, T., \& Slooff. I. P., Acta paediat., Uppsala, 1932, XIV, 19.

Monrad, S., ibid., 1927-28, VII, 28.

Munting, W., Monatschr. f. Kinderh., Berlin, 1933, LV, 341.

Nissen, R., \& Boecker, P., Deutsche Ztchr. f. Chir., Berlin, 1933, CCXLI, 34.

Peiffer, J., Les indications thérap. dans. la sténose hypertr. du pylore, Strasbourg.

Rammstedt, C., Deutsche med. Wchnschr., Leipzig, 1930, LVI, 348.

Schnohr, E., Acta paediat., Uppsala, 1933, XIV, 49.

Seckel, H., Jahrb. f. Kinderh., Berlin, 1933, CXXXX, 263.

Tisdall, F. F., Poole, M. W., \& Brown, A., Am. J. Dis. Child., Chicago, 1927, XXXIV, 180.

Usener, W., Ztschr. $f$. Kinderh., Berlin, 1926, XXXXI, 176

Wernstedt, W., Jahrb. f. Kinderh., Berlin, 1907, LXV, 674; Monatschr. f. Kinderh., Berlin, 1909, VIII, 524.

Wiedhopf, O., \& Brühl, H., Deutsche Ztschr. f. Chir., Perlin, 1933, CCXXXVIII, 653.

Willi, H., Jahrb. f. Kinderh., Berlin, 1933, CXXXVIII, 259.

Wolff, S., ibid., 1930, CXXVIII, 287. 